EDUKACJA MIĘDZYKULTUROWA

\title{
„Sfery życia duchowego dzieci, młodzieży i dorosłych w środowiskach zróżnicowanych kulturowo"
}

\section{Cieszyn-Ustroń, 22-24 września 2014 roku}

W dniach 22-24 września 2014 roku w Cieszynie i w Ustroniu odbyła się XX konferencja naukowa organizowana przez Zakład Pedagogiki Ogólnej i Metodologii Badań oraz Zakład Pedagogiki Społecznej i Edukacji Międzykulturowej cieszyńskiego Wydziału Etnologii i Nauk o Edukacji Uniwersytetu Śląskiego. Współorganizatorami międzynarodowej konferencji były Wyższa Szkoła Pedagogiczna ZNP w Warszawie, Stowarzyszenie Wspierania Edukacji Międzykulturowej oraz Centrum Pedagogiczne dla Polskiego Szkolnictwa Narodowościowego w Czeskim Cieszynie.

Trzydniowe spotkanie rozpoczęto uroczyście w Ratuszu Miejskim w Cieszynie, gdzie zebranych powitał burmistrz Cieszyna mgr inż. Mieczysław Szczurek, w imieniu Komitetu Naukowego Konferencji głos zabrał prof. zw. dr hab. Tadeusz Lewowicki, a władze uczelni reprezentowali dziekan Wydziału Etnologii i Nauk o Edukacji w Cieszynie dr hab. prof. UŚ Zenon Gajdzica oraz dyrektor Instytutu Nauk o Edukacji WEiNoE w Cieszynie dr hab. prof. UŚ Urszula Szuścik. Po uroczystym otwarciu konferencji rozpoczęto merytoryczną część obrad naukowych.

To szczególne wydarzenie naukowe stanowiło kontynuację rozważań podjętych na poprzednich konferencjach. Tym razem głównym obszarem dyskusji uczyniono zagadnienia życia duchowego dzieci, młodzieży i dorosłych funkcjonujących w środowiskach zróżnicowanych kulturowo, jak również konteksty teoretyczne pedagogiki międzykulturowej i problemy praktyki oświatowej. Skoncentrowano się na kilku obszarach tematycznych - sferach kluczowych dla życia duchowego jednostek, grup i społeczności funkcjonujących w warunkach wielokulturowości, a mianowicie: wartościach i aspiracjach; religii i tolerancji religijnej; kontaktach z Innym i innością; szansach 
i barierach pracy nauczyciela w warunkach wielokulturowości oraz na teoretycznym i metodologicznym podejściu do kwestii edukacji w środowiskach zróżnicowanych kulturowo.

Merytoryczny program konferencji obejmował trzy dni i cztery sesje naukowe w formie wymiany poglądów, dyskusji, wspólnie formułowanych wniosków, tez i sugestii badawczych. Taka forma spotkań sprawia, że pożytki poznawcze i rekomendacje badawcze w dużej mierze zależą od udziału uczestników w kolejnych częściach całej konferencji. W drugim dniu wydarzeniu temu towarzyszyła również wystawa posterów. Natomiast wyjątkowe w tegorocznej konferencji było nie tylko tradycyjne już uczestnictwo przedstawicieli wiodących ośrodków naukowych z Polski, ale również gości zagranicznych z Czech (Univerzita Tomáše Bati ve Zlíně), Niemiec (Freie Universität Berlin), Słowacji (Univerzita Konštantína Filozofa v Nitre) i Ukrainy (Київський університет імені Бориса Грінченка). Dodatkowo zapewniono także oprawę kulturalną spotkania, koncert Orkiestry Salonowej, spektakl teatralny Těšínské divadlo - Scena Polska w Czeskim Cieszynie. W drugim dniu konferencji odbyła się sesja wyjazdowa „Duchowe i materialne dziedzictwo kulturowe Śląska Cieszyńskiego".

Moderowanie pierwszej części spotkania odbywającej się w cieszyńskim Ratuszu („Wartości i aspiracje oraz religia i tolerancja religijna w środowiskach zróżnicowanych kulturowo") powierzono prof. zw. dr. hab. Zenonowi Jasińskiemu, doc. PhDr., PhD Jaroslavowi Balvinowi, dr. hab. prof. UMCS Dariuszowi Kubinowskiemu oraz dr hab. prof. UMK Marcie M. Urlińskiej. Podczas tej części spotkania naukowego wysłuchać można było wystąpienia prof. zw. dr hab. Katarzyny Olbrycht (Uniwersytet Śląski) dotyczącego miejsca wychowania w rozwoju duchowości współczesnego człowieka. Następnie dr hab. Marek Rembierz (Uniwersytet Śląski) podjął problematykę wartości ponadkulturowych (prawdy, dobra i piękna) w kontekście zróżnicowania religijnego i pluralizmu światopoglądowego, wskazując na edukację międzykulturową jako ćwiczenie duchowe. W tej części obrad można było również wysłuchać wystąpienia prof. zw. dr. hab. Jerzego Nikitorowicza (Uniwersytet w Białymstoku) dotyczącego sztuki duchowości na przykładzie Międzynarodowego Festiwalu Muzyki Cerkiewnej w Białymstoku (Festiwalu Śpiewającej Duszy). W kolejnym referacie dr hab. Dorota Misiejuk (Uniwersytet w Białymstoku) podjęła tematykę doświadczenia kulturowego jednostki w odniesieniu do kategorii tradycji, próbując odpowiedzieć na pytanie, czy możliwy jest przekaz wielokulturowy. W dalszej części spotkania głos zabrali 
kolejni uczestnicy, kontynuując rozważania na temat zaproponowanej w sesji problematyki. Jako pierwszy dr hab. prof. UwB Mirosław Sobecki (Uniwersytet w Białymstoku) przedstawił dwa rodzaje zaangażowania religijnego i ich konsekwencje dla edukacji międzykulturowej, mówiąc o duchowości i kompetencjach w sferze semiotycznej. Dr Jolanta Muszyńska (Uniwersytet w Białymstoku) w swoim referacie wskazywała na znaczenie religii w relacjach społecznych mieszkańców północno-wschodniego pogranicza Polski. Następnie jeden z zagranicznych gości, asoc. prof. PhD., DrSc Hristo Kyuchukov (Freie Universität Berlin, Niemcy) podjął problem kompetencji językowych dzieci romskich, prezentując badania zespołu, którym kieruje. $\mathrm{Na}$ zakończenie tego dnia obrad prof. zw. dr hab. Zenon Jasiński (Uniwersytet Opolski) przedstawił, jakie są oczekiwania środowisk zróżnicowanych kulturowo wobec nauczycieli.

Podczas drugiej - ustrońskiej - sesji naukowej („Kontakty z Innym i innością jako wartość w warunkach wielokulturowości”) prowadzonej przez dr hab. prof. SGGW Krystynę M. Błeszyńską, prof. zw. dr. hab. Jerzego Nikitorowicza, dr. hab. prof. UwB Mirosława Sobeckiego oraz prof. dr. hab. АюАмила Хоружа, jako pierwszy głos zabrał dr hab. prof. UMCS Dariusz Kubinowski (Uniwersytet Marii Curie-Skłodowskiej w Lublinie). Wystąpienie dotyczyło tradycji tanecznych pogranicza wieloetnicznego Polski północno-wschodniej i ich współczesnych rekonstrukcji. Następnie mgr Urszula Namiotko (Uniwersytet w Białymstoku) mówiła o transmisji dziedzictwa kulturowego na przykładzie działań teatrów niezawodowych regionu Sejneńszczyzny. Wpisując się w problematykę tej sesji, dr Przemysław Paweł Grzybowski (Uniwersytet im. Kazimierza Wielkiego w Bydgoszczy) zainteresował uczestników zagadnieniem uśmiechu na styku sfer prywatnej i publicznej w warunkach zróżnicowania kulturowego. Powrót do korzeni: rodzimowierstwo jako droga rekonstrukcji poczucia wspólnoty i tożsamości to referat zaproponowany przez dr hab. prof. SGGW Krystynę M. Błeszyńską (Szkoła Główna Gospodarstwa Wiejskiego w Warszawie). Po tym wystąpieniu dr hab. Barbara Grabowska, dr Aniela Różańska, dr Urszula Klajmon-Lech (Uniwersytet Śląski) dokonały prezentacji badań zespołowych na temat znaczenia wspólnoty, postrzegania inności i tolerancji religijnej na pograniczu. Po podsumowaniu dotychczasowych wystąpień i dyskusji kontynuowano obrady w sekcji, rozpoczynając od wystąpienia dr. hab. prof. SWPS Jacka Kurzępy (Szkoła Wyższa Psychologii Społecznej we Wrocławiu) na temat młodzieży pogranicza w kontekście Przystanku Woodstock i Przystanku Je- 
zus i ewentualnej konfrontacji czy dialogu tych obu społeczności. Następnie swoimi zainteresowaniami badawczymi dzielili się z uczestnikami dr Barbara Chojnacka-Synaszko, dr Jolanta Suchodolska, dr Łukasz Kwadrans (Uniwersytet Śląski), prezentując badania zespołowe na temat kontaktów z Innym i innością w środowisku zróżnicowanym kulturowo (studium z pogranicza polsko-czeskiego). Swoje doniesienie z badań na temat świata wartości dzieci cudzoziemskich przedstawiła dr Agata Świdzińska (Uniwersytet Marii Curie-Skłodowskiej w Lublinie). Referat na temat wiedzy i stosunku do mniejszości narodowych i etnicznych jako elementu kompetencji interkulturowej studentów zaprezentowały dr Ilona Nowakowska-Buryła, dr Marzena Okrasa (Uniwersytet Marii Curie-Skłodowskiej w Lublinie). Mgr Emilia Żyłkiewicz-Płońska (Uniwersytet w Białymstoku), prowadząc badania opinii wśród mobilnych studentów, zwróciła uwagę na kwestię szacunku wobec osób odmiennych kulturowo. Zespół gości ze Słowacji w składzie: doc. PhDr. Michal Kozubík, PhD., Mgr Lenka Michelčíková, PhD., PhDr. Ivan Rác, PhD. (Univerzita Konštantína Filozofa v Nitre, Słowacja) prezentował referat będący raportem z badań na temat życia duchowego Romów w regionie „Podtatrzańskim" i wschodniej Słowacji. Kolejny referat to wystąpienie dr. hab. prof. WSB Marka Walancika (Wyższa Szkoła Biznesu w Dąbrowie Górniczej) dotyczący praktycznego wymiaru edukacji dzieci romskich w Polsce na przykładzie województwa śląskiego. Po tej części nastąpiły podsumowanie sesji i wnioski.

Obradom towarzyszyła sesja posterowa przedstawicieli Uniwersytetu Śląskiego, w której wyniki swoich badań i refleksji naukowych prezentowały: dr Janina Urban („Tożsamość młodzieży autochtonicznych mniejszości narodowych krajów Grupy Wyszehradzkiej i ich szkoła w procesach integracyjnych Europy - nastawienia i brak obaw”), dr Natalia Ruman („Obraz śmierci w oczach pszczyńskiej młodzieży ponadgimnazjalnej”), mgr Aleksandra Gancarz („Przejawy religijności Sybiraków w Związku Radzieckim - zbiorowości hetero- i homogeniczne wyznaniowo”), mgr Katarzyna Jas („Pogranicze polsko-czeskie jako miejsce aktywności osób starszych”), mgr Alicja Hruzd-Matuszczyk („Życie kulturalne rodzin poza granicami kraju”) oraz lic. Karolina Czech („Wspólnoty ewangelikalne na Śląsku Cieszyńskim”).

W poszukiwaniu „Duchowego i materialnego dziedzictwa kulturowego Śląska Cieszyńskiego" uczestnicy konferencji udali się na sesję wyjazdową, podczas której mieli możliwość spotkania się z prof. zw. dr. hab. Danielem Kadłubcem i zwiedzania Muzeum regionalnego „Na Grapie” w Jaworzynce, które zostało otwarte 19 czerwca 1993 roku z inicjatywy wielkiego miłośni- 
ka cieszyńskiej ziemi, poety i pisarza Jerzego Ruckiego. Rucki urodził się w Jaworzynce w 1919 roku, lecz losy wojenne rzuciły go do Szwajcarii, gdzie zamieszkiwał aż do śmierci. Przez całe życie na obczyźnie czuł jednak więź z miejscem swojego dorastania. Pisał wiersze oraz opowieści związane z Jaworzynką, posługując się archaiczną gwarą zakątka istebniańskiego. Śladem pozostawionym po nim stały się tomiki wierszy, zbiory wspomnień, a przede wszystkim zorganizowane przez niego muzeum, pokazujące skrawek dawnego życia miejscowych górali.

Konferencję kończyła IV sesja poświęcona „Teoretycznym i metodologicznym aspektom edukacji w środowiskach zróżnicowanych kulturowo”. Tę część prowadzili prof. dr hab. Анна Григорьевна Кондратенко, doc. PhDr. Michal Kozubík, PhD., dr hab. prof. SWPS Jacek Kurzępa, dr hab. Dorota Misiejuk. Prezentacji swoich referatów, doniesień z badań, refleksji nad problematyką podnoszoną w sekcji dokonał na początku zespół w składzie: dr hab. prof. UŚ Ewa Ogrodzka-Mazur, dr Aleksandra Minczanowska, dr Gabriela Piechaczek-Ogierman (Uniwersytet Śląski) na temat badań własnych dotyczących wartości, aspiracji i planów życiowych dzieci z Zaolzia - ciągłość i zmiana transmisji kulturowej w środowisku pogranicza. Następnie dr hab. Anna Gajdzica (Uniwersytet Śląski) przedstawiła rozważania na temat szans i zagrożeń pracy nauczyciela w warunkach wielokulturowości - doświadczeń i praktyki. Zespół dr hab. prof. UMK Marta M. Urlińskiej, wraz z dr Katarzyną Jurzystą oraz lic. Sylwią Szulc (Uniwersytet Mikołaja Kopernika w Toruniu) przedstawił prezentację dotyczącą nauczyciela polskiego na obczyźnie jako partnera lub intruza, wskazując na trzy perspektywy - łotewską, pol-

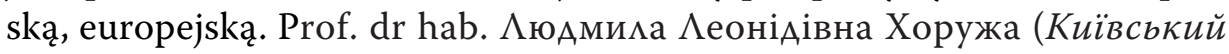
університет імені Бориса Грінченка, Ukraina) przedstawiła referat pt. „Этика педагогического взаимодействия преподавате я и студента как основа Аичностного и профессионацьного совершенствования". Natomiast kolejna z uczestniczek zagranicznych, prof. dr hab. Анна Григорьевна Кондратенко (Київський університет імені Бориса Грінченка, Ukraina), prezentowała wystąpienie na temat „Ценности студентов-музыкантов на этапе аАаптации к обучению в университете". Referaty gości z Ukrainy dopełniły obrady tej części sesji naukowej. W dalszej części spotkania uczestnicy mieli możliwość wysłuchania wystąpień prof. zw. dr hab. Iwony Nowakowskiej-Kempnej (Akademia im. Jana Długosza w Częstochowie) na temat duchowości franciszkańskiej - ekologii i harmonii wewnętrznej jako postawy dzieci na ziemi cieszyńskiej w Polsce i Republice Czeskiej. Magister 
Agnieszka Niewiara (Wyższa Szkoła Biznesu w Dąbrowie Górniczej) zajęła się zagadnieniem bibliodramy w edukacji międzykulturowej. Kolejny referat PhD. Jakuba Hladíka (Univerzita Tomáše Bati ve Zlíně, Republika Czeska) dotyczył znaczenia wielokulturowych kompetencji dla nauczycieli i uczniów szkół podstawowych w Czechach. Natomiast doc. PhDr., PhD Jaroslav Balvin (Univerzita Tomáše Bati ve Zlíně, Republika Czeska) podjął temat wielokulturowości i andragogiki. „Pamiętaniem” - jako „kłopotem metodologicznym” w badaniach biograficznych w środowiskach zróżnicowanych kulturowo zajęła się dr Adela Kożyczkowska (Uniwersytet Gdański). Na koniec tej sesji dr Natalia Bednarska (Wyższa Szkoła Pedagogiczna ZNP w Warszawie) wskazała na możliwość wykorzystania netnografii jako metody badania społeczności wielokulturowych. Konferencję naukową zakończyła dyskusja uczestników, w której wielokrotnie powracano do wątków podejmowanych podczas całego spotkania. O tym, że stanowiły one inspirację oraz budziły ciekawość poznawczą uczestników, świadczy fakt, że wielokrotnie prowadzone dyskusje przenosiły się w kuluary.

Po końcowej dyskusji podsumowania trzydniowych obrad dokonał przewodniczący Komitetu Naukowego prof. zw. dr hab. Tadeusz Lewowicki. W swojej wypowiedzi wskazał na dotychczasowy dorobek współpracujących ośrodków naukowych i zasygnalizował potrzebę prowadzenia dalszych badań oraz wymiany doświadczeń w obszarze edukacji międzykulturowej.

Pragniemy dodać, iż wyjątkowy charakter tegorocznej konferencji wyznaczał jubileusz 25-lecia Zakładu Pedagogiki Ogólnej, którego wieloletnim kierownikiem i przewodnikiem naukowym był i pozostaje prof. zw. dr hab. Tadeusz Lewowicki. Rocznica działalności zakładu sprawiła, że spotkanie naukowe było czasem szczególnej refleksji, analizy dotychczasowych dokonań naukowych oraz wyznaczenia nowych obszarów poszukiwań badawczych realizowanych przez zebranych gości indywidualnie oraz zespołowo. Cieszyńsko-ustrońskie spotkanie było również przyczynkiem do przemyśleń o zakończonych, realizowanych bądź planowanych projektach badawczych, które zostały zainspirowane przez prof. zw. dr. hab. Tadeusza Lewowickiego. 